\title{
Blocking Type Immunoglobulins in Patients with Nongoitrous Primary Hypothyroidism in Area of Iodine Deficinecy
}

\author{
Te TANG, Yin-Gu WANG*, Kumiko TSUBOI**, Minoru IRIE**, \\ TAI MA, AND SIDNEY H. INGBAR ${ }^{\dagger}$ \\ Department of Pathophysiology, Tianjin Medical College, Tianjin, \\ *The Institute of Endemic Diseases for Prevention and Control, \\ Xinjiang Akesu, China, and **First Department of Internal \\ Medicine, Toho University School of Medicine, Tokyo 143, \\ Japan
}

\begin{abstract}
We have evaluated the role of circulating serum immunoglobulins (IgG) which inhibit the growth of thyroid in the etiology of thyroid atrophy in endemic cretinism. Twenty nongoitrous cretins (13 women and 7 men, age range: 9-33) were classified on the basis of clinical criteria for cretinism in China. They were born and living in an iodine deficient area, Xinjiang, northwest China. Antimicrosomal antibody titers were negative in all serum. Nine patients (seven women and two men; age range: 11-23) were biologically primary hypothyroid. Seven subjects were of a myxedematous form and two subjects were of a mixed form. We have studied thyroid-growth inhibiting immunoglobulin (TGII) activity that was measured as an inhibitory effect of $4 \mathrm{mg} / \mathrm{ml} \operatorname{IgG}$ on TSH-induced $\left[{ }^{3} \mathrm{H}\right]$-thymidine incorporation into the DNA of a rat thyroid follicular cell line, FRTL $\mathrm{F}_{5}$ cells. Six (five women and one man) out of the nine patients with primary hypothyroidism (66.7 percent) had TGII. We also measured other growth-blocking IgG that inhibited $\left[{ }^{3} \mathrm{H}\right]$-thymidine incorporation into DNA stimulated by insulin-like growth factor-I (IGF-I), a growth factor working through a cAMP-independent pathway. Five (three women and two men) out of nine patients (55.6 percent) with nongoitrous primary hypothyroidism had IGF-I-blocking IgG. These results indicate that TGII plays an important role in atrophy of the thyroid in spite of increased serum TSH concentrations, and IgG which inhibits thyroid growth stimulated by IGF-I also might play a role in thyroid atrophy in some endemic cretins. An autoimmune process might be involved in the pathogenesis of hypothyroidism secondary to thyroid atrophy, though severe iodine deficiency is a cause of endemic cretinism.
\end{abstract}

Key words: Endemic cretinism, Nongoitrous cretin, Iodine deficiency, Thyroid atrophy, Thyroid-growth inhibiting immunoglobulin (TGII), IGF-I-blocking IgG.

(Endocrinol Japon 38: 661-665, 1991)

CRETINISM RESULTS from an inadequate output of thyroid hormone during a critical growth phase of intrauterine and postnatal life. Severe

Received: July 12, 1991

Accepted: November 22, 1991

Correspondence to: Dr. Kumiko TSUBOI, First Department of Internal Medicine. Toho University School of Medicine, 6-11-1 Ohmori-nishi, Ohta-ku, Tokvo 143, Japan.

This work was done at the Charles A Dana Research Institute and the Harvard-Thorndike Laboratories of Beth Israel Hospital, Boston, USA.

‘ Deceased. iodine deficiency is a cause of hypothyroidism. Endemic goiter is usually prevalent in areas of severe iodine deficiency. The participating factors in the pathogenesis of thyroid atrophy in chronic iodine deficiency are not yet known. Previous studies have revealed the presence of inhibiting immunoglobulins $(\operatorname{IgG})$ which block the action of $\mathrm{TSH}$ in patients with autoimmune thyroid disease $[1,2]$. Some patients with primary myxedema have reported having Thyroid-Growth-Inhibiting $\operatorname{Ig} G$ (TGII) measured as a blocking effect on TSH- 
induced DNA-synthesis in the thyroid [3, 4]. We have reported that $\operatorname{IgG}$ in some patients with nongoitrous primary hypothyroidism contained, in addition to TGII, some that inhibited ${ }^{3} \mathrm{H}$ thymidine incorporation into DNA of rat thyroid follicular cell line, FRTL $L_{5}$ stimulated by insulinlike growth factor-I (IGF-I), a growth factor that worked through a cAMP-independent pathway [5].

The passive transfer of maternal TSH-blocking antibodies is a cause of neonatal hypothyroidism, but the disease is transient following the disappearance of the antibodies [6]. Therefore, there are few reports indicating that such blocking antibodies result in permanent hypothyroidism [7, 8]. To understand the role of an immunological mechanism in the etiology of thyroid atrophy in endemic cretinism, we investigated the effects of circulating serum $\operatorname{IgG}$ fractions from nongoitrous cretins in an area of iodine deficiency, Xinjiang, northwest China, on thyroid growth.

\section{Materials and Methods}

\section{Patients}

The subjects were born and living in an iodine deficient area (iodine in the drinking water: 3.5 $\mu \mathrm{g} / l, \quad 24 \mathrm{~h}$ urinary excretion of iodine: $19.09 \pm 14.92 \mu \mathrm{g} / \mathrm{g}$ creatinine), Xinjiang, northwest China. Twenty nongoitrous cretins (13 women and 7 men; age range: 9-33) were classified on the basis of clinical criteria for cretinism in China (Table 1) [9]. Five subjects were of a neurologic form (Group I), 8 subjects were of a myxedematous form (Group II) and 7 subjects were of a mixed form (Group III). Anti-microsomal antibody titers were measured by the haemagglutination method (Thymune-M, Wellcome Diagnostics, England). TSH, total thyroxine $\left(\mathrm{T}_{4}\right)$ and triiodothyronine $\left(\mathrm{T}_{3}\right)$ were measured with radioimmunoassay kits (GammaDab and GammaCoat kits Clinical assays, Travenol, Cambridge, MA).

\section{Materials}

The reagents and laboratory supplies used in these studies were obtained from the following sources; highly purified bovine TSH $(30 \mathrm{IU} / \mathrm{mg})$ used for studies of the effects of TSH on growth was kindly provided by the National Hormone and Pituitary Program NIDK-NIH (Baltimore, MD); Coon's modified Ham's F-12 tissue culture medium (Coon's F-12 medium) was from Hazelton-KC Laboratories (Kansas City, KS); calf serum was from GIBCO Laboratories (Grand Island, NY); trypsin 1-300 was from ICN Biochemicals (Cleveland, OH). Transferrin, insulin and partially purified bTSH used in the maintenance of cell culture were purchased from Sigma Chemical Company (St. Louis, MO). Bovine serum albumin (BSA) Fraction $\mathrm{V}$ was from Calbiochem Biochemicals (La Jolla, CA). Recombinant IGF-I (thr ${ }^{59}$ IGF-I) was purchased from Amgen Biologicals (Thousand Oaks, CA). [Methyl- $\left.{ }^{3} \mathrm{H}\right]$-thymidine (5.5 $\mathrm{mCi} / \mathrm{mmol}$ ) was from DuPont NEN Research Products (Boston, MA). Protein A-Sepharose CL$4 \mathrm{~B}$ was purchased from Pharmacia Fine Chemicals (Uppsala, Sweden).

\section{Growth-blocking assay}

Immunoglobulins $(\operatorname{Ig} G)$ were prepared by precipitation with ammonium sulfate followed by purification with Protein A-Sepharose CL-4B affinity column chromatography. $\operatorname{IgG}$ was dialyzed and lyophilized. Measurement of the incorporation of $\left[{ }^{3} \mathrm{H}\right]$-thymidine into the DNA of FRTL cells was done by methods previously described [10]. In brief, the cells were maintained with Coon's F-12 medium supplemented with 5\% calf

Table 1. Clinical criteria of cretinism in China $(1980)^{(9)}$

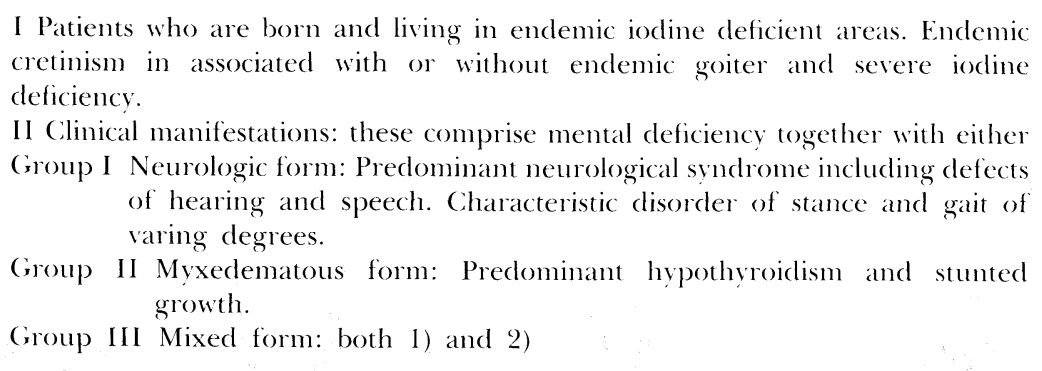


serum and the hormones bTSH $(1 \mathrm{mU} / \mathrm{ml})$, insulin $(1 \mu \mathrm{g} / \mathrm{m} l)$ and transferrin $(5 \mu \mathrm{g} / \mathrm{m} l)$. After preincubation with hormone-free medium for 5 to 10 days, the cells were incubated with Coon's-F-12 medium containing $0.1 \%$ BSA (growth assay medium) and $4 \mathrm{mg} / \mathrm{m} l \mathrm{IgG}$ with an appropriate concentration of the test agent $\left(10^{-10} \mathrm{M} \mathrm{TSH}\right.$, or $1.33 \mathrm{nM}$ IGF-I). After $42 \mathrm{~h}$ incubation, the media were replaced with $5 \mu \mathrm{Ci} / \mathrm{ml}\left[{ }^{3} \mathrm{H}\right]$-thymidine and the cells were incubated for an additional $3 \mathrm{~h}$. Cellular macromolecules were precipitated with $10 \%$ ice-cold trichloroacetic acid, solubilized with $2 \%$ SDS, and counted in a liquid scintillation sepectrometer. TGII activity and IGF-I-blocking activity were expressed as an inhibitory effect of 4 $\mathrm{mg} / \mathrm{m} / \operatorname{IgG}$ on $\left[{ }^{3} \mathrm{H}\right]$-thymidine incorporation into DNA stimulated by TSH and IGF-I, respectively. The Normal range was determined by data for the mean $\pm 2 \mathrm{SD}$ of nine normal control individuals living in an iodine sufficient non-endemic area.

\section{Results}

Anti-microsomal antibody titers were negative in all serum. Seven subjects in Group II and two subjects in Group III had high thyrotropin levels in serum. Table 2 shows the serum concentrations of $T_{4}, T_{3}$, and TSH in nine patients with biochemically primary hypothyroidism ( 7 women and 2 men; age range: $11-23)$. In all nine patients except

Table 2. Peripheral thyroid hormone concentrations in endemic cretins

\begin{tabular}{ccccc}
\hline Patients & \multicolumn{5}{c}{$\begin{array}{c}\text { Total } \mathrm{T}_{1} \\
\mu \mathrm{g} / \mathrm{m} l\end{array}$} & $\begin{array}{c}\text { Total } \mathrm{T}_{3} \\
\mathrm{ng} / \mathrm{ml} l\end{array}$ & $\begin{array}{c}\text { Basal TSH } \\
\mu \mathrm{U} / \mathrm{m} l\end{array}$ \\
\hline Group II: myxedematous form & & \\
1 & $11 / \mathrm{F}$ & 2.0 & 78 & 88 \\
2 & $14 / \mathrm{F}$ & 2.0 & 200 & 70 \\
3 & $18 / \mathrm{F}$ & 0.6 & 50.9 & 48 \\
4 & $23 / \mathrm{M}$ & 1.3 & 69.3 & 40 \\
5 & $14 / \mathrm{F}$ & 2.0 & 140 & 17.4 \\
6 & $20 / \mathrm{M}$ & 3.5 & 62.3 & 12 \\
7 & $20 / \mathrm{F}$ & 3.5 & 166 & 10 \\
Group & III: $\mathrm{mixed}$ form & & \\
8 & $16 / \mathrm{F}$ & 1.1 & 44.5 & 48 \\
9 & $16 / \mathrm{F}$ & 9.4 & 250 & 16.5 \\
& & & & \\
& & $4.5-11.5$ & $80-200$ & $<5$ \\
\hline
\end{tabular}

Patients were nongoitrous cretins who were born and living in an iodine deficient area in Xinjiang, northwest China. Individual hormones were measured with radioimmunoassay kits.
Table 3. TGII and IGF-I-blocking in endemic cretins in Xinjiang

\begin{tabular}{lcccc}
\hline $\begin{array}{c}\text { Patients } \\
\text { age/sex }\end{array}$ & $\begin{array}{c}\text { Basal TSH } \\
\mu \text { U/ml }\end{array}$ & $\begin{array}{c}\text { TGII } \\
\text { inhibition }\end{array}$ & $\begin{array}{c}\text { IGF-I-blocking } \\
\text { \% inhibition }\end{array}$ \\
\hline 1 & $11 / \mathrm{F}$ & 88 & 50.5 & 5.2 \\
2 & $14 / \mathrm{F}$ & 70 & 49.5 & 59.5 \\
3 & $18 / \mathrm{F}$ & 48 & 58.9 & 33.2 \\
8 & $16 / \mathrm{F}$ & 48 & 60.0 & 70.2 \\
4 & $23 / \mathrm{M}$ & 40 & 13.6 & 35.5 \\
5 & $14 / \mathrm{F}$ & 17.4 & 55.0 & 63.8 \\
9 & $16 / \mathrm{F}$ & 16.5 & 17.0 & 31.2 \\
6 & $20 / \mathrm{M}$ & 12 & 47.8 & 54.3 \\
7 & $20 / \mathrm{F}$ & 10 & 10.7 & 6.8 \\
\multicolumn{7}{c}{ Normal } & $<5$ & $<44.4$ & $<34.1$ \\
\hline
\end{tabular}

Patients were nongoitrous primary hypothyroidism in an iodine deficient area. TGII and IGF-I-blocking were measured as inhibitory effects of $4 \mathrm{mg} / \mathrm{ml} \operatorname{IgG}$ on TSH- or IGF-I-induced $\left[{ }^{3} \mathrm{H}\right]$ thymidine incorporation into DNA of $\mathrm{FRTL}_{5}$ cells, expressed as \% inhibition.

one (No. 6), the serum $T_{3} / T_{4}$ ratio was increased. The upper normal limits of TGII activity and IGF-I-blocking activity were $44.4 \%$ and $34.1 \%$, respectively, in nine control subjects. Nine samples of serum from patients with primary hypothyroidism were tested for blocking activity. Individual data on TGII activity and IGF-I-blocking activity are given in Table 3. Six (five women and one man) out of the nine patients with nongoitrous primary hypothyroidism (66.7 percent) had TGII. Five (three women and two men) out of nine patients (55.6 percent) had IGF-I-blocking activity. Four patients had both TGII and IGF-I-blocking activity, and one patient had TGII alone, one patient had IGF-I-blocking alone. Two patients, No. 7 and No. 9 who had mild hypothyroidism did not have either TGII or IGF-I blocking IgG. None of the $\operatorname{IgG}$ itself stimulated the basal $\left[{ }^{3} \mathrm{H}\right]-$ thymidine uptake.

\section{Discussion}

The purpose of this study was to evaluate the role of an immunological mechanism in the etiology of thyroid atrophy in endemic cretinism. The clinical diagnosis of primary hypothyroidism must be confirmed by a typical biochemical picture of thyroid failure characterized by low $\mathrm{T}_{4}$ and high TSH. In a textbook [11], the authors stated that one cannot depend on laboratory evidence of 
thyroid dysfunction to assist in the diagnosis of endemic cretinism, because the structural and functional peculiarities of the cretin are legacies of his or her past thyroid hormone deficiency, and thyroid function may be entirely normal in endemic cretins. However, we must consider the possibility of patients with neurological signs and symptoms caused by undernutrition or unknown environmental factors in utero. Since endemic cretinism in China was diagnosed without measuring the serum concentration of thyroid hormones [9], we evaluated serum total $\mathrm{T}_{4}$, total $\mathrm{T}_{3}$ and $\mathrm{TSH}$ concentrations before studying the immunological aspects. We obtained nine serum samples with increased TSH concentrations indicating primary hypothyroidism, including a patient whose $T_{4}$ value was within the normal range (subclinical hypothyroidism). Thyroid adapts to iodine deficiency by increasing the production of hormones, especially triiodothyronine through TSH stimulation. Normal or slightly increased $\mathrm{T}_{3}$ and/or an increased $T_{3}$ to $T_{4}$ ratio were observed in the serum of eight subjects in the present study.

There are three clinical forms of endemic cretins, neurological, myxedematous and mixed form. Myxedematous cretins usually have clearcut biochemical signs of thyroid failure, low levels of serum $T_{4}$ and increased serum TSH. In contrast, in neurological cretins, these signs are usually absent or only minor. In 20 cases of cretinism in the present study, 11 cases ( 5 neurologic form, 1 myedematous form and 5 mixed form) have some neurological signs and symptoms without increased TSH. We consider possibility of the condition being caused by some agent, perhaps dietary, which causes early damage to the thyroid, and we obtained nine serum samples with typical features of primary hypothyroidism.

In endemic goiter, the adaptive processes are triggered and remain controlled by increased secretion of TSH. Thyroid growth is also controlled by growth factors such as EGF, besides TSH. Previous studies have revealed the presence of inhibiting $\mathrm{IgG}$ which blocks the TSH-binding to its receptor [1], TSH-induced cyclic AMP accumulation [2] and TSH-induced growth of thyroid cells $[3,4,5]$ in patients with autoimmune thyroid disease. The reports of neonatal hypothyroidism secondary to placental transfer of the maternal antibodies have recently appeared but the disease was transient following the disappearance of the antibodies [6]. In our cases, the disease was permanent, and anti-microsomal antibody titers were not increased by the haemagglutination method which did not indicate conventional autoimmune thyroid diseases such as Hashimoto's disease. The fact that six out of nine patients $(66.7 \%)$ with nongoitrous primary hypothyroidism in this study has TGII indicates that TGII contributes to atrophy of the thyroid in spite of increased serum TSH concentrations.

Since maternal $T_{4}$ during pregnancy might play a vital role in early fetal neurologenesis before the onset of fetal thyroid function, the degree of maternal hypothyroidism might be an important factor in the mechanism of psychomoter delay or mental delay [12]. We did not measure the blocking antibodies in the mothers. We also did not have any information indicating whether the mothers were hypothyroid during the whole pregnancy period, were euthyroid, or had been treated. However, maternal hypothyroidism may cause congenital abnormalities but not congenital hypothyroidism. Fetal and maternal thyroid glands are exposed independently but simultaneously to the same environmental factors. We would not consider our subjects cases of cretinism simply caused by maternal hypothyroidism.

It has been suggested that TSH-receptor antibody with TSH antagonist activity (blocking $\operatorname{IgG}$ ) is responsible for thyroid atrophy in patients with primary atrophic thyroiditis. Thyrotropin-binding inhibitor immunoglobulin (TBII) activity is measured as an inhibitory effect on TSH-binding to the receptor, and the activity of thyroidstimulation blocking antibodies (TSBAb) is measured as an inhibitory effect on cAMP response. Both activities indicate TSH-receptor mediated inhibitory effects. We did not have enough serum to measure both TBII and TSBAb, so we measured TGII activities alone. We are not able to evaluate whether the $\operatorname{IgG}$ works through the TSH-receptor. We concentrate and focus on thyroid growth or growth-blocking, instead of TSHreceptor binding or cAMP response.

Many growth factors have been found to stimulate thyroid cell growth and indicate that factors other than TSH are capable of stimulating thyroid growth. We have previously shown that IGF-I like TSH is a potent mitogen for FRTL5 cells and synergistic enhancement of DNA synthesis [13]. Ovine thyroid cells in a primary culture have been 
shown to produce the insulin-like growth factors and the production of growth factors was stimulated by TSH [14]. The possibility exists that TSH may not stimulate growth directly but rather a growth-promoting effect may be produced by intermediary growth factors. We have reported that $\operatorname{IgG}$ in some patients with autoimmune atrophic thyroiditis contains in addition to TGII, IGF-I-blocking IgG that inhibited IGF-Istimulated DNA synthesis in the thyroid [5]. Thus, some IgG can block growth effects elicited separately from the TSH receptor. In this study, we demonstrate the presence of IGF-I-blocking IgG in serum from some nongoitrous endemic cretins in addition to TGII. Interestingly, patient No. 4 did not have TGII but had IGF-I-blocking IgG. The thyroid might have shrunken not through the action of TGII but that of IGF-I-blocking IgG. We cannot yet explain why two patients (No. 7 and No. 9) had neither TGII nor IGF-I-blocking IgG in serum. Since the $\operatorname{IgG}$ itself did not stimulate the basal $\left[{ }^{3} \mathrm{H}\right]$-thymidine uptake, we may conclude that there was no significant contamination by growth factors including TSH.

The present study reveals that an autoimmune process might be involved in the pathogenesis of hypothyroidism secondary to thyroid atrophy, though severe iodine deficiency is a cause of endemic cretinism.

\section{References}

1. Endo K, Kasagi K, Konishi J, Ikekubo K, Okuno T, Takeda Y, Mori T, Torizuka K (1978) Detection and properties of TSH-binding inhibitor immunoglobulins in patients with Graves' disease and Hashimoto's thyroiditis. J Clin Endocrinol Metab 46: 734.

2. Konishi J, Iida Y, Endo K, Misaki T, Nohara Y, Matsuura N, Mori T, Toritsuka K (1983) Inhibition of thyrotropin-induced adenosine 3', 5'monophosphate increase by immunoglobulins from patients with primary myxedema. J Clin Endocrinol Metab 57: 544-549.

3. Drexhage HA, Bottazzo GF, Bitensky L, Chayen J, Doniach D (1981) Thyroid growth-blocking antibodies in primary myxoedema. Nature 289: 594-596.

4. Iida Y, Konishi J, Kasagi K, Misaki T, Arai K, Tokuda Y, Torizuka K (1987) Inhibition of thyrotropin-induced growth of rat thyroid cells, FRTL-5, by immunoglobulin $\mathrm{G}$ from patietns with primary myxedema. J Clin Endocrinol Metab 64: 124-130.

5. Tsuboi K, Irie M, Cho BY, Ingbar SH (1989) Thyroid-growth-inhibiting antibodies in patients with nongoitrous autoimmune hypothyroidism. In: Lee M, Koh S-C, Eastman CJ, Nagataki S (eds) Progress in Thyroidology 1989. 135.

6. Matsuura N, Yamada Y, Nohara Y, Konishi J, Kasagi K, Endo K, Kojima H, Wataya K (1980) Familial neonatal transient hypothyroidism due to maternal TSH binding immunoglobulins. $N$ Engl J Med 303: 738-741.

7. Van der Gaag RD, Drexhage HA, Dussault J
(1985) Role of maternal immunogloblins blocking TSH-induced thyroid growth in sporadic forms of congenital hypothyroidism. Lancet I: 246-250.

8. Boyages SC, Halpern J-P, Maberly GF, Eastman CJ, Chen J, Zhen-Hua W, Van der Gaag RD, Drexhage HA (1989) Endemic cretinism: Possible role for thyroid autoimmunity. Lacnet II: 529.

9. Ma T (1980) Selected scientific works of endemic goiter and endemic cretinism. Academic conference on endemic goiter and endemic cretinism, Huixian, Henan, 96.

10. Tramontano D, Cushing GW, Moses AC, Ingbar SH (1986) Insulin like growth factor I stimulates the growth of rat thyroid cells in culture and synergizes the stimulation of DNA synthesis induced by TSH and Graves' IgG. Endocrinol 119: 940.

11. DeGroot LJ (1985) Endemic goiter and related disorders. In: The Thyroid and Its Diseases, 5th ed, John Wiley \& Sons, New York, 657.

12. Matsuura N, Konishi J, group (1990) Transient hypothyroidism in infants born to mothers with chronic thyroiditis-A nationwide study of twentythree cases. Endocrinol Japon 37: 369-379.

13. Tramontano D, Moses AC, Picone R, Ingbar SH (1987) Characterization and regulations of the receptor for insulin-like growth factor-I in the FRTL5 rat thyroid follicular cell line. Endocrinol 120: 785 .

14. Eggo MC, Burrow GN (eds) (1985) Thyroglobulin - the Prothyroid Hormone. Raven Press, New York. 